\title{
Variability of Omega-3/6 Fatty Acid Obtained Through Extraction-Transesterification Processes from Phaeodactylum tricornutum
}

\author{
Mari Carmen Ruiz-Domínguez, ${ }^{1, \star}$ Constanza Toledo, ${ }^{1}$ Daniel Órdenes, ${ }^{1,2}$ \\ Carlos Vílchez, ${ }^{3}$ Paula Ardiles, ${ }^{1}$ Jenifer Palma ${ }^{1}$ and Pedro Cerezal ${ }^{1}$ \\ ${ }^{1}$ Laboratorio de Microencapsulación de Compuestos Bioactivos, (LAMICBA), Departamento de Ciencias de los Alimentos \\ y Nutrición, Facultad de Ciencias de la Salud, Universidad de Antofagasta, 1240000 Antofagasta, Chile \\ ${ }^{2}$ Departamento de Tecnología Médica, Facultad de Ciencias de la Salud, Universidad de Antofagasta, \\ 1240000 Antofagasta, Chile \\ ${ }^{3}$ Algal Biotechnology Group, CIDERTA and Faculty of Sciences, University of Huelva, 21007 Huelva, Spain \\ *Corresponding author: E-mail: maria.ruiz@uantof.cl
}

Received: $12-22-2020$

\begin{abstract}
The effect of direct transesterification methods on the omega-3/6 composition of extracts from Phaeodactylum tricornutum was studied. The aim of this work was to identify an extraction method which allowed to obtain the most suitable profile of fatty acids in terms of its potential benefits to health, particularly if further used in the food industry. Seven methods using acids, alkalis, and heterogeneous-catalysts, (namely methods from 1 to 7 , abbreviated as M1-M7) were performed to determine $a$-linolenic (ALA), linoleic (LA), docosahexaenoic (DHA) and eicosapentaenoic (EPA) acids. The composition of fatty acids was in all cases characterized by the major abundance of palmitic (23.95-34.08\%), palmitoleic (30.94-35.56\%), oleic acids (3.00-7.41\%), and EPA (0.5-6.45\%). Unsaturated fatty acids extraction yield was higher with a two-step transesterification process (M6, 63.65\%). The total fatty acid methyl ester content (FAME) obtained with acid-transesterification (M1) reached about $21 \% \mathrm{wt}$, and $60 \% \mathrm{w} / \mathrm{w}$ total lipids. ALA higher relative content (ALA/LA ratio) was obtained when a lipid pre-extraction step was performed prior to acid-catalysis (M4). The transesterification method based on alkali-catalyst (M3, KOH catalyst) led to obtain higher DHA relative contents (DHA/EPA ratio up to 0.11), although its FAME content was 3.75-fold lower than that obtained with acid-transesterification (M1). Overall, this study shows that direct transesterification with alkali-catalyst (M3) improves the determination of PUFA content from the diatom through a more efficient transesterification-based extraction process, and thus allow to assess the value of the biomass more accurately for application in the food industry.
\end{abstract}

Keywords: diatom; lipids; fatty acids; DHA/EPA; ALA/LA; PUFA

\section{Introduction}

Microalgae cultivation has gained much interest these days because of the need for renewable resources with the ability to synthesize valuable products such as pigments, carbohydrates, and fatty acids, among other compounds. ${ }^{1,2}$ Phaeodactylum tricornutum, in particular, is a model pennate diatom used for physiological studies and biotechnological food and nutritional applications. ${ }^{3,4}$ This diatom is known for its rapid growth and antioxidant capacity owing to fucoxanthin (carotenoid) and/or long-chain polyunsaturated fatty acids (PU-
FAs). ${ }^{5-7}$ P. tricornutum is one of the few microalgae species that can produce high levels of eicosapentaenoic acid (EPA; C20:5n-3), along with low levels of docosahexaenoic acid (DHA; C22:6n-3) and arachidonic acid (ARA; $20: 4 n-6) .{ }^{8}$ This ability is relevant to the biotechnological industry since PUFAs have beneficial human health effects.

DHA and EPA are essential nutrients that play an important role in infant growth and development, along with adult cardiovascular health. ${ }^{9,}{ }^{10}$ Accordingly, several reports demonstrate that consuming a diet rich in ome- 
ga-3 polyunsaturated fatty acids such as DHA and EPA is useful for lowering blood triacylglycerol (TAG) levels in people with hypertriglyceridemia. In addition, intake of PUFA-rich oils have been found to play relevant roles in mitigation of inflammation, disease activity, and oxidative stress biomarkers, through increased levels of antioxidant enzymes ${ }^{13}$. This can be of importance to develop novel foods and nutraceuticals that help prevent or attenuate chronic inflammatory disease $\mathrm{e}^{13}$, and can also be relevant to mind, cardiovascular ${ }^{11,12}$, inflammatory ${ }^{13}$ and immune ${ }^{10}$ health care, and even cancer prevention ${ }^{14}$.

Because of its importance, a DHA/EPA ratio is outlined based on the ideal design of diet for fish larvae in aquaculture production, although the optimum ratio varies depending on species. ${ }^{15}$ However, there are growing concerns about the role of essential fatty acids in the regulation of animal metabolism. ${ }^{16-18}$ An overview of recommended daily dietary intake of DHA and EPA in humans ranges from $0.5 \mathrm{~g} /$ day for infants to $1 \mathrm{~g} /$ day for adults and patients with coronary heart diseases..$^{19,20}$

Omega- 3 fatty acids are synthesized from their precursors, $\alpha$-linolenic (C18:3n-3; ALA) and linoleic acid (C18:2n-6; LA), which are also present in P. tricornutum. ALA and LA are considered essential fatty acids in humans because they cannot be synthesized and must be obtained from the diet. ${ }^{21}$ Briefly, Fig.1S (can be seen in the supplementary material section which was adapted from Guo, et $a .^{22}$ and Arao and Yamada ${ }^{23}$ ) shows the omega-3/6 synthesis pathway where a sequence of desaturation (DES) and elongation (ELO) steps catalyzed by desaturase and elongase enzymes, respectively $(\Delta-5$ and $\Delta-6)$ along with fatty acyl-CoA synthetase lead to the formation of longer chain fatty acids. ${ }^{24,25}$ Consumption of food with the optimal omega-3/6 ratio is crucial in maintaining the overall health of the human population. ${ }^{26}$ According to previous reports, high LA intake can induce production of proinflammatory cytokines triggered by the release of arachidonic acid (ARA)-derived products. ${ }^{27-29}$ Thus, LA intake must be balanced with that intake of other PUFA (optimal omega-3/6 ratio), based on their daily needs. At the same time, the conversion of ALA to EPA/DHA can compete with the biosynthesis of EPA and DHA from LA, due to the competitive inhibition of enzymes ( $\Delta-5$ DES and $\Delta-6$ DES, see Fig. 1S). ${ }^{30}$

These facts make $P$. tricornutum species the ideal candidate for possible biotechnological evaluations, particularly involving PUFA production. ${ }^{5,6,31}$

Transesterification reaction between glycerides (microalgal oils) and alcohol (methanol or ethanol) in the presence of a catalyst results in the production of fatty acid methyl esters (FAMEs) or fatty acid ethyl esters (FAEEs), respectively with glycerol as the by-product. ${ }^{32,33}$ The catalyst can be an alkali, acid, or even an enzyme (heterogeneous catalyst) and its selection could in turn, produce variability in the fatty acid profile obtained through transesterification. ${ }^{34-36}$ Consequently, getting the profiles of extracted unsaturated fatty acids and DHA/EPA ratios to be adequate for specific applications, namely food, depends not only on the growth conditions of specific microalgal strains but also on the chemical factors determining the extraction process. ${ }^{31,37,38}$ In this regard, the selection of a suitable transesterification method becomes crucial to obtain a targeted fatty acid profile for food applications.

Based on this, we hypothesized that temperature and catalyst chemical nature of the transesterification process should have an impact on the extraction yield, which might result in improved, selective extraction of specific fatty acids in relation to others. This can be of relevance to production of PUFA-enriched foods that are based on addition of microalgal fatty acids. Thus, this study aims to determine the most effective transesterification reaction among seven independent methods using different catalyst forms (alkali or acid), in order to improve the analytical determination of unsaturated fatty acids (omega-3). Special attention is given to ALA, LA, DHA and EPA from P. tricornutum as these fatty acids are of high value for food applications.

\section{Experimental}

\section{1. Material}

Phaeodactylum tricornutum was provided by the microalgal collection department in "Laboratorio Microalgas y Compuestos Bioactivos" (Universidad de Antofagasta, Chile) and cultured under controlled conditions. Local seawater, sterilized and filtered through 1 $\boldsymbol{\mu} \mathrm{m}$ pore size filters was used to prepare the culture medium, which was supplemented with $\mathrm{f} / 2$ salts, silicates, and vitamins as described by Guillard and Ryther ${ }^{39}$ The biomass was harvested at the end of the exponential growth phase and then lyophilized in the freeze-drying system (Labconco Freezone 2.5 L Benchtop Freeze Dry System, USA) for this study. Sulfuric acid $\left(\mathrm{H}_{2} \mathrm{SO}_{4}\right)$, potassium hydroxide $(\mathrm{KOH})$, and potassium carbonate $\left(\mathrm{K}_{2} \mathrm{CO}_{3}\right)$ were used as acid or alkali catalysts (analytical grade reagents). Methanol $(\mathrm{MeOH})$, chloroform $\left(\mathrm{CHCl}_{3}\right)$, and $n$-hexane of chromatographic quality were used as extraction solvents (Sigma-Aldrich). Mixed FAME standard solutions (FAME Mix C4-C24, Supelco Analytical) and an internal standard (NuCheck Pre, Inc., Elysian, MN, USA) were used for fatty acid identification.

\section{2. Lipid Analysis}

Lipids were extracted as described by Axelsson and Gentili $^{40}$ using $20 \mathrm{mg}$ of freeze-dried samples of from $P$. tricornutum with chloroform: methanol $(2: 1, \mathrm{v} / \mathrm{v})$ as the solvent. The extracted lipids were quantified gravimetrically in triplicate $(\mathrm{n}=3)$. 


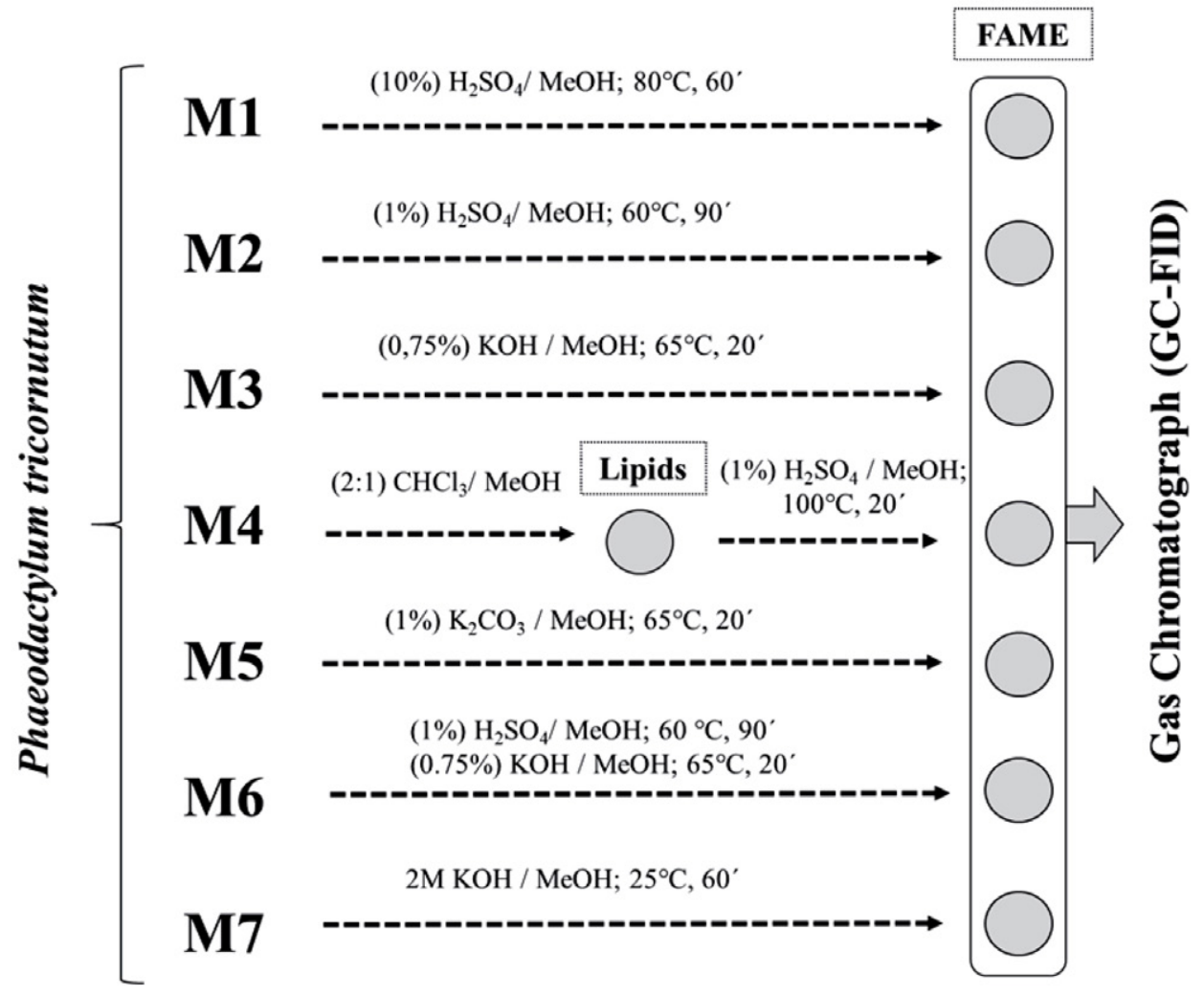

Fig. 1 Experimental design using P. tricornutum to obtain FAME. M1-M7 are the abbreviations of seven independent transesterification methods used in the study, as described in Material and Methods section $(p<0.05 ; n=3)$.

\section{3. Transesterification Methods}

The extraction of fatty acid methyl esters (FAMEs) was carried out through seven independent methods (using alkaline or acid catalysts), as shown in Fig. 1.

M1 was performed according to Lamers, et al. ${ }^{41} \mathrm{M} 2$ and M3 included independent acid and alkali transesterification reactions, respectively, and were as described by Rahman, et al. ${ }^{42}$ M4 and M5 followed the method of Sung and $\mathrm{Han}^{43}$, where in M4 was performed by pre-extraction of lipids followed by acid transesterification, and M5 was performed on the biomass directly using an alkaline heterogeneous catalyst such as $\mathrm{K}_{2} \mathrm{CO}_{3}$. M6 was performed using a two-step transesterification reaction, where the first step was the acid process, and the second step was the alkaline process, according to Rahman, et al. ${ }^{42}$ Finally, M7 was carried out according to ISO-5508 ${ }^{44}$ In general, the reaction mixture was prepared by adding 10-50 mg freeze-dried biomass of $P$. tricornutum (with biomass: solvent ratio of 1:30) and $10 \mathrm{ppm}$ of the internal standard with continuous agitation. Then, the flasks were washed with $3 \mathrm{~mL}$ hexane and Milli-Q water until the solution turns neutral, and the mixture was separated into two layers by centrifugation $(360 \mathrm{~g}, 10 \mathrm{~min})$. The upper oil layer (FAMEs diluted in hexane) was separated and washed with Milli-Q water to analyze and quantify using gas chromatography (Shimadzu 2010 GC-FID, Tokyo, Japan).

\section{4. Fatty Acid Analysis by Gas Chromatography (GC-FID)}

A Shimadzu 2010-gas chromatography system equipped with a flame ionization detector (FID) and a split/splitless injector was used to analyze FAME composition. FID is one of the most commonly used detectors in gas chromatography and it works by passing the previously volatilized organic sample through a flame generated from pure hydrogen and compressed air. Then, these ions are detected by a biased electrode located close to the flame. In all cases, samples $(1 \mu \mathrm{L})$ were injected into a capillary column RESTEK $(30 \mathrm{~m}, 0.32$ $\mathrm{mm}$ i.d., $0.25 \mu \mathrm{m}$ film thickness). The injector temperature was maintained at $250{ }^{\circ} \mathrm{C}$ in split mode with a split ratio of 1:20, and nitrogen was used as the carrier gas at a constant flow rate of $1.25 \mathrm{~mL} / \mathrm{min}$. The oven temperature was programmed initially at $80{ }^{\circ} \mathrm{C}$ for $5 \mathrm{~min}$, increased to $165^{\circ} \mathrm{C}$ at $4{ }^{\circ} \mathrm{C} / \mathrm{min}$ for $2 \mathrm{~min}$, and then increased again to $180{ }^{\circ} \mathrm{C}$ at $2{ }^{\circ} \mathrm{C} / \mathrm{min}$ for $5 \mathrm{~min}$. It was heated at a rate of $2{ }^{\circ} \mathrm{C} / \mathrm{min}$ to $200^{\circ} \mathrm{C}$ for $2 \mathrm{~min}$ followed by $4{ }^{\circ} \mathrm{C} / \mathrm{min}$ to $230^{\circ} \mathrm{C}$ for $2 \mathrm{~min}$ and was finally maintained at that temperature for 2 min reaching $250^{\circ} \mathrm{C}$ at 2 ${ }^{\circ} \mathrm{C} / \mathrm{min}$. The detector temperature was maintained at $280^{\circ} \mathrm{C}$. Individual FAMEs were identified by comparing their retention times with those of mixed FAME standards (FAME Mix C4-C24, Supelco Analytical) and quantified by comparing their peak area with those of mixed 
FAME standards and an internal standard (tripentadecanoin $\sim 10 \mathrm{ppm} / \mathrm{sample}$, Nu-Check Pre, Inc., Elysian, MN, USA). Finally, FAME content was calculated as a percentage in relation to freeze-dried biomass (\% wt.) and total lipids $(\% \mathrm{w} / \mathrm{w})$ of $P$. tricornutum.

\section{5. Statistical Analysis}

To investigate the statistical differences between fatty acid profiles, ALA/LA, and DHA/EPA ratios of P. tricornutum, the means of different methods were obtained in triplicate $(\mathrm{n}=3)$. Then, Analysis of Variance (ANOVA) followed by Duncan's Multiple Range Test (MRT) was applied as a post hoc test to measure the specific differences between means values. Analyses were performed with Statgraphics Centurion XVIII (Stat Point Technologies, Inc., Warrenton, VA, USA) software.

\section{Results and Discussion}

\section{1. Fatty Acid Profile}

The effect of each of the seven different transesterification methods on the P. tricornutum FA profile is shown in Table 1 and expressed as the percentage of relative abundance of total fatty acids (Insert Table 1 near here). Firstly, M6 (two-step transesterification process), the only method where both acid and alkaline catalysts were used in each one of the steps, produced the highest unsaturated fatty acid content in the diatom extracts, when compared to the other transesterification methods (51.08\% MUFAs and $14.42 \%$ PUFAs, monounsaturated and polyunsaturated fatty acids). M6 especially stood out in oleic (5.05\%), linoleic (LA, 4.01\%), a-linolenic (ALA, 2.07\%) and eicosapentaenoic (EPA) acid content (6.45\% of total fatty acids, FA). Secondly, the acid transesterification methods such as M1 and M2 gave rise to similar FA profiles in P. tricornutum, with higher EPA content in extracts obtained by $\mathrm{M} 1$ and higher docosahexaenoic (DHA) content in those obtained by M2 (6.05\% and $0.32 \%$ FA, respectively). Both ALA (omega-3) and LA (omega-6) fatty acids are essential for humans and must be obtained through their daily di$\mathrm{et}^{21}$; microalgae are valuable natural sources of these essential fatty acids. ${ }^{20,45,46}$ However, the presence of ALA was minimum in both M1 and M2 acid transesterification methods (n.d., (not detected) equal to area $\leq 10^{-3}$ ) when compared to LA (from 2.92 to $4.42 \% \mathrm{FA}$ ). It is important to remark that the main difference between M1 and M2 methods was the percentage of acid catalyst used. Catalyst concentration is an important factor directly influencing the yield of FAMEs. ${ }^{47}$ Macías-Sánchez, et al.$^{48}$ studied the potential of Nannochloropsis gaditana as a source of biodiesel by direct transesterification method utilizing three different catalyst concentrations, including, $2.5,5$, and $10.5 \%$ of acetyl chloride and obtained maximum yields with $5 \%$ catalyst.

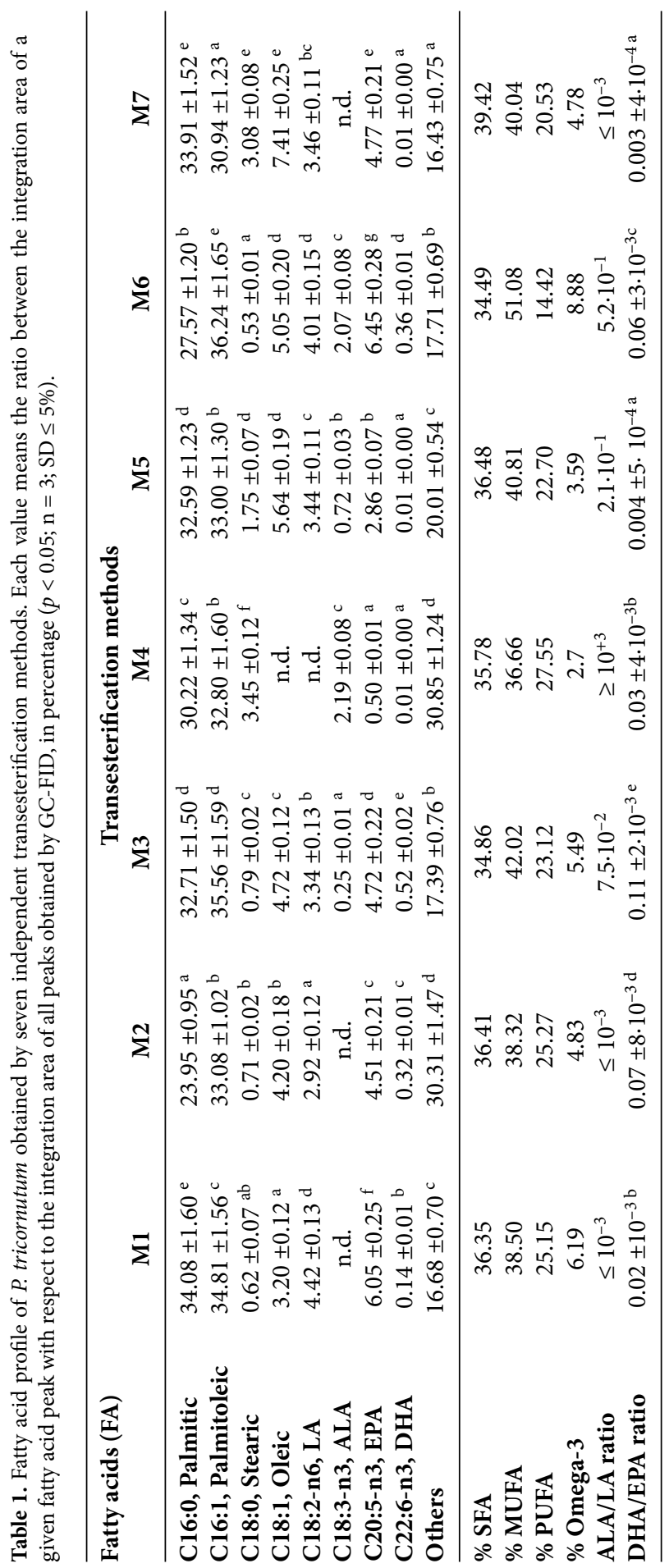

Note: All values were $\mathrm{SD} \leq 5 \%$.

Abbreviators: Methylation (M), Fatty acids (FA), Linoleic (LA), Linolenic (ALA), Eicosapentaenoic (EPA), Docosahexaenoic (DHA), Saturated Fatty acids (SFA), Monounsaturated Fatty acids (MUFA), Polyunsaturated fatty acids (PUFA), non-detected (n.d.; area $\leq 10^{-}$ ${ }^{3}$ ), Omega-3: main $\mathrm{n}-3$ fatty acids present in $P$. tricornutum. They were obtained taking into account all fatty acids integrated (included others profile). Different superscript letters from "a" to "g" indicate statistically significant differences $(\mathrm{p}<0.05)$. All results are the average of three independent experiments $(n=3)$ and are presented as mean \pm standard deviation. 


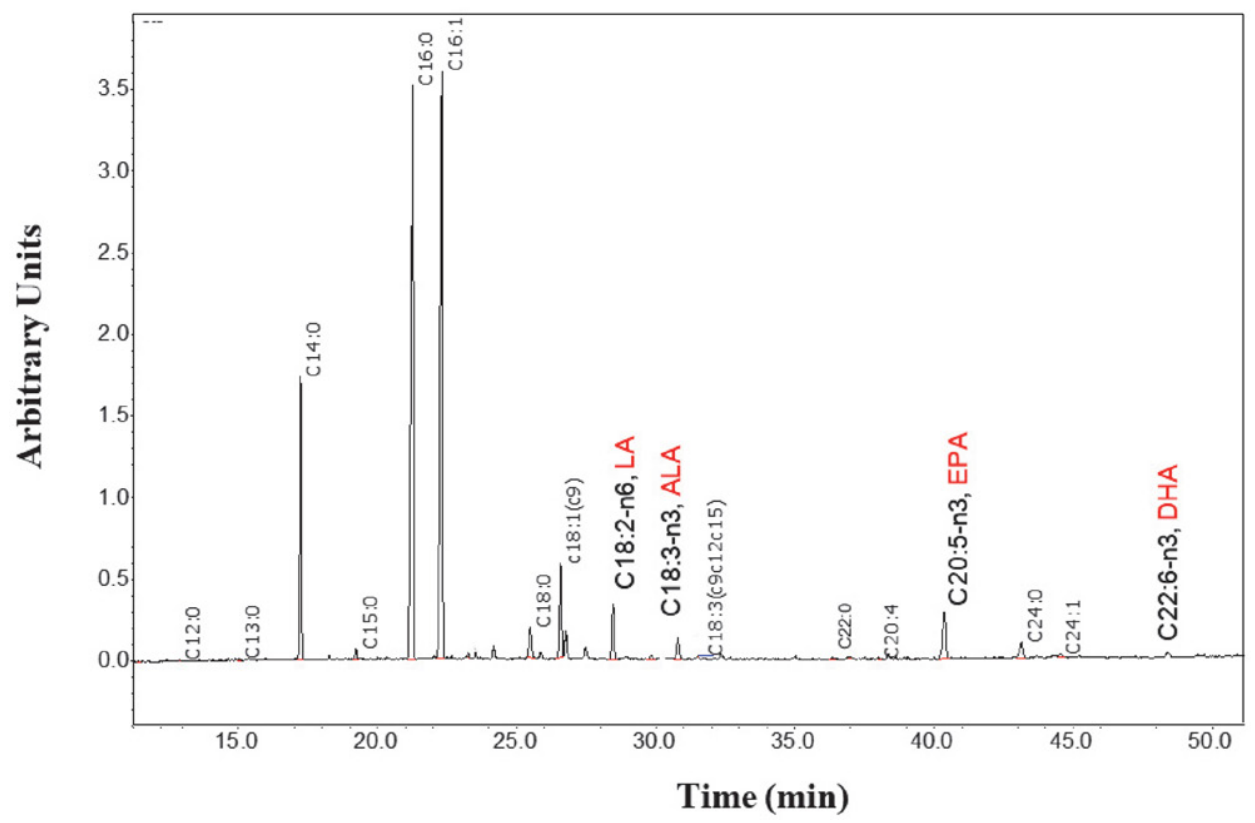

Fig. 2. Representative chromatogram of fatty acids profile present in P. tricornutum. Note: the method used was M5 (alkali method).

The alkali-based transesterification with methanol was also tested. The procedures of M3 and M7 were performed with different $\mathrm{KOH}$ concentrations and temperatures, while $\mathrm{M} 5$ was performed with $\mathrm{K}_{2} \mathrm{CO}_{3}$. In all cases, the PUFA profiles of $P$. tricornutum were similar with higher EPA content being obtained in the M3 and M7 methods (4.72 and 4.77 FA, respectively). Moreover, M7 had the highest percentage of oleic acid (7.41\% FA), and M3 had the highest yield of DHA (0.52\% FA). Omega 3 -fatty acids content is also presented in Table 1 . The values shown in the Table are the results of the addition of the three omega-3 fatty acids identified in P. tricornutum extracts: ALA, EPA and DHA. The highest omega 3-fatty acids content in the extracts was obtained with methods M6 and M1 (8.88 and 6.19\% FA, respectively). The heterogeneous catalysts (for instance, method M6, two-step transesterification) has been described as one of the most promising tools due to its ability to catalyze both free fatty acids and triglycerides in transesterification reactions at the same time ${ }^{49}$. In particular, M6 led to a fatty acid composition which could benefit the design of functional foods with positive health effects in humans.

All transesterification methods extracted a similar proportion of palmitic (C16:0, from 23.95 to $34.08 \% \mathrm{FA}$ ) and palmitoleic acids (C16:1, values from 30.94 to $36.24 \%$ FA) present in P. tricornutum. Particularly, palmitoleic acid was the most abundant component in the fatty acids profile of this strain, as described in previous reports. ${ }^{4,7}$ Different studies have demonstrated that this monounsaturated fatty acid increases the insulin sensitivity in the liver and muscle of diabetic rats improving hyperglycemia and hypertriglyceridemia problems. ${ }^{50,51}$. Arsić, et al. ${ }^{52}$ even demonstrated that elite athletes might contribute to positive effect in their physical performance through higher percentages of palmitoleic acid and arachidonic acid in plasma and in erythrocytes.

On the other hand, M5 had a more diversified fatty acid composition, as can be seen from the chromatogram in Fig. 2. Finally, M4 (pre-extraction of lipids followed by acid transesterification) led to less abundant PUFA content for all extracts, and only oleic acid and ALA content (3.45\% and $2.19 \% \mathrm{FA}$, respectively) could be highlighted.

According to reports, the best transesterification methods for microalgal oils involve sodium hydroxide or potassium hydroxide as the alkaline catalysts. ${ }^{49,53}$ The most commonly used acid catalysts include sulfuric acid, hydrochloric acid, or sulfuric acid derivatives. Heterogeneous catalysts are also known as metal oxides or carbonates and result in methoxide formation. ${ }^{54-56}$ Studies report that alkali-catalyzed transesterification is faster than acid-catalyzed transesterification, and it is also less corrosive and cost-effective from an industrial point of view. ${ }^{55,57,58}$ However, it is known that the alkali catalyst can react with free fatty acids present in the microalgal oils provoking soap formation. Moreover, it can also inhibit the efficiency of separation of glycerol from methyl esters, thus lowering the transesterification yield. ${ }^{59}$ In general, our results showed improved levels of PUFAs and omega-3, especially EPA, in P. tricornutum under acid and twostep transesterification reactions (M1 and M6, respectively).

Fig. 3 shows the FAME content of $P$. tricornutum, which was calculated relative to biomass (\% wt) and total lipids $(\% \mathrm{w} / \mathrm{w})$ in the seven transesterification methods. Average total lipid content of about $35 \%$ was reached in all extracts of $P$. tricornutum. 


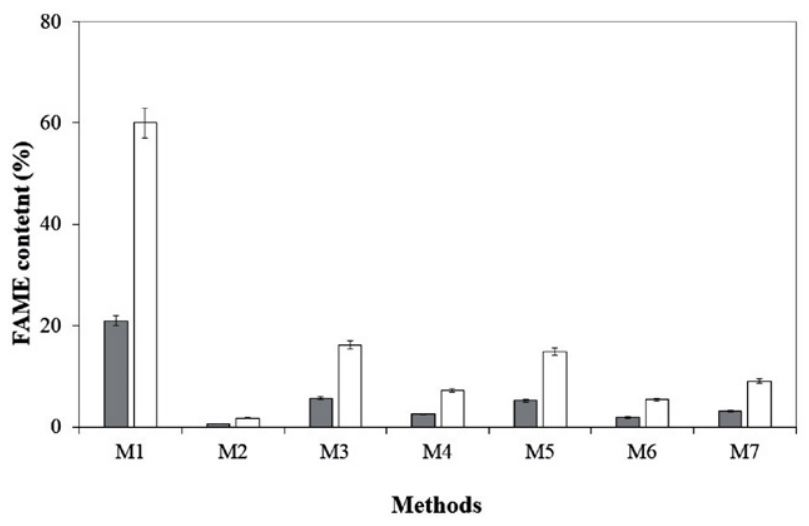

Fig. 3. Total FAME fraction in total lipids (\% w/w total lipids, open bars) or in the biomass (\% wt, solid bars) of P. tricornutum from seven independent transesterification methods $(\mathrm{p}<0.05 ; \mathrm{n}=3)$. Note. wt: percentage in relation to freeze-dried biomass.

Accordingly, method M1 yielded the highest content of FAMEs in P. tricornutum, with $\sim 21 \% \mathrm{wt}$. and $\sim 60 \% \mathrm{w} / \mathrm{w}$ of the total biomass and total lipids, respectively. Below M1 yield, the alkali methods M3 and M5 gave rise to FAME contents of $5.65 \% \mathrm{wt}$ and $16.20 \% \mathrm{w} / \mathrm{w}$ of the total lipids and $5.22 \% \mathrm{wt}$. and $14.90 \% \mathrm{w} / \mathrm{w}$ of the total lipids, respectively. The acid method M2 resulted in the lowest FAME content $(0.62 \%$ wt. and $1.76 \% \mathrm{w} / \mathrm{w}$ of the total lipids).

Conversely, these results differ from several other reports that describe that alkaline catalysis has higher conversion levels of triglycerides to their corresponding methyl esters with shorter reaction times. ${ }^{60,61}$ The results in this paper show improved FAME content for acid transesterification when compared to previous reports. Typically, acid-catalyzed transesterification is more tolerant toward free fatty acids or water presence and catalyzes both esterification and transesterification reactions at the same time. ${ }^{62,63}$ Nevertheless, the results obtained with methods $\mathrm{M} 1$ and M2 show significant variations with different proportions of $\mathrm{H}_{2} \mathrm{SO}_{4}$ being used as the only difference between both processes. The difference in yield obtained is probably because a high concentration of the catalyst is always required in acid transesterification to achieve high FAME yields. ${ }^{64,65}$

\section{2. ALA/LA ratio in Phaeodactylum Tricornutum}

The significance of the $\alpha$-linolenic to the linoleic acid ratio (ALA/LA ratio) in the diatom extracts is worth analyzing and discussing. According to the data shown in Table 1 , the presence of ALA in the extracts obtained by employing the M1, M2, and M7 transesterification methods was negligible (not detected, n.d. area $\leq 10^{-3}$ ). Conversely, an abundance of LA ranging from $2.92 \%$ to $4.92 \%$ of the total fatty acid content was found in the extracts. Thus, the methods M1, M2, and M7 lead to very low ALA/LA ratios.
On the contrary, the methods M3, M4, M5, and M6 present ALA/LA ratios that differ widely from those previously commented. Mainly, the ratio fluctuates from 7.5 for method M3 to a very high value for method M4 (LA not determined).

Interestingly, M4, consisting of a lipid pre-extraction step followed by acid catalysis, is highly selective for $a$-linolenic extraction concerning LA. The differential selectivity of the method used for ALA and LA acids enables the production of $P$. tricornutum extracts enriched in either one of these fatty acids. However, as discussed above, the method produces selective extraction of ALA, which is suitable to stimulate the biochemical synthesis of EPA and DHA in humans, while limiting the presence of LA in the extracts, thereby preventing the organisms from having reduced n-3 long-chain PUFA levels.

The above-commented selectivity may directly influence the food applications of the diatom extracts. Linolenic acid tends to occur at much lower levels in the diet and the tissues of the body when compared to linoleic acid. $^{66}$ As seen in Fig. 1S (can be seen in supplementary material), ALA can undergo successive desaturation and elongation reactions to biosynthesize the polyunsaturated fatty acids EPA and DHA while LA competes with ALA $(18: 3 n-3)$ for such endogenous conversion to EPA and DHA. ${ }^{30,66}$ In addition, LA also inhibits the incorporation of DHA and EPA into tissues leading to low levels of $n-3$ long-chain PUFAs ${ }^{67}$, which is of crucial importance during pregnancy and infancy. Accordingly, the use of transesterification methods to produce ALA-enriched, LA free extracts can be of value for producing food-grade supplements aimed at balancing the biochemical needs for ALA in humans.

\section{3. DHA/EPA Ratio in Phaeodactylum Tricornutum}

The DHA/EPA ratio in P. tricornutum was also examined using seven independent transesterification methods. Anew, Table 1 shows the results of the application of Duncan's MRT. Our data revealed that the M3 method (using the alkali catalyst $\mathrm{KOH}(0.75 \% \mathrm{w} / \mathrm{v})$ ) was the best transesterification method with a DHA/EPA ratio of $\sim 0.11$ in P. tricornutum and was significantly different from the rest. It was followed by M2 (acid process) and M6 (twostep transesterification) methods with the DHA/EPA ratio ranging between $0.07-0.05$. Although M2 had an improved DHA/EPA ratio, it was not consistent with regard to FAME content (Fig. 3). Qiao, et al. ${ }^{3}$ calculated the DHA/ EPA ratio in $P$. tricornutum under different culture conditions and obtained lower values than our results with a range between $\sim 0.03-0.06$. It was found that temperature was the factor that improved the ratio. This ratio is relevant in the aquaculture field because its proportion plays a significant role in considering sources for preparing feed formulation for the fast-growing stages of fish. ${ }^{68}$ 
It is also necessary to obtain microalgae culture with a moderate DHA/EPA ratio because they are the initial food for larvae and are required for improving their growth, nonspecific immunity and disease resistance. ${ }^{16,69}$ DHA is an essential structural component of the neural tissues, such as the brain and eyes, and is also a significant component of polar lipids. ${ }^{70}$ At the same time, EPA is more relevant as a precursor for the synthesis of bioactive compounds that help the effects of DHA, such as the hormone eicosanoids. ${ }^{71}$ In fact, these eicosanoids formed from EPA have also been shown to act as a potent regulator of oxidative damage triggered by injury and inflammation in humans, demonstrating beneficial effects against rheumatoid arthritis as a chronic disease $\mathrm{e}^{13}$ or promoting immune function. ${ }^{72}$

Therefore, this ratio is also relevant in human health for controlling hypertriglyceridemia among other anomalies. For this application, the food supplement should yield a DHA/EPA ratio of $0.7: 1 .{ }^{73}$ Also, specific aquaculture reports show that the dietary requirement of DHA/EPA ratios in marine fish should range from 0.5 to 2.0 , according to Council ${ }^{74}$ These results clearly demonstrate the variation of the DHA/EPA ratio obtained with different transesterification methods. These results may be useful for the production of aquaculture feed or supplements rich in PUFAs and DHA/EPA ratios.

\section{Conclusions}

In this work an extraction process leading to obtain a valuable composition of microalgal fatty acids -namely PUFA- for being potentially used in food applications was selected out of several transesterification methods. P. tricornutum diatom was used as reference biomass. Our results show the influence the transesterification methods can have on the fatty acid composition and content of microalgal extracts. The transesterification methods assayed with $P$. tricornutum showed fatty acid profiles that are all rich in MUFA and PUFA (mainly omega-3). Specifically, the two-step transesterification method (M6, with acid and alkaline process) improved the selective composition of unsaturated fatty acids (51.08\% MUFAs and $14.42 \%$ PUFAs) and omega- 3 content ( $8.88 \% \mathrm{FA})$ in the diatom extracts. Increased relative contents of ALA (ALA/LA) and DHA (DHA/EPA ratios) in P. tricornutum extracts, was found by following the alkaline M3 process when compared to others. The acid transesterification (M1) method was found to enhance the fatty acid content with $\sim 21 \%$ wt and $\sim 60 \% \mathrm{w} / \mathrm{w}$ of the total biomass and total lipids, respectively. Thereupon, we proved that the careful selection of the transesterification method is a key tool for producing selectively PUFA-enriched microalgal extracts. The fatty acids ALA, LA, EPA and DHA can be taken as reference components for selecting a suitable method as they are of great relevance to human food and feed indus- tries, among others. According to the obtained results, we suggest that the most recommendable transesterification-based extraction method should be selected as a function of either (or both) highest total PUFA content or/ and high relative content of a targeted PUFA, according to the further specific application.

\section{Acknowledgments}

Our research group "LAMICBA" thanks "Laboratorio Microalgas y Compuestos Bioactivos Microalgas" at University of Antofagasta, Chile for providing microalgal samples. In addition, this research was financed by several projects belonging to national public resources ANID (National Agency for Research and Development of Chile, previously CONICYT) and the University of Antofagasta. They are codified as PAI-79160037, FONDECYT-11170017, and Undergraduate Thesis Scholarship Fund-649/19, respectively.

\section{Conflict of Interests Statement}

The authors declare that there is no conflict of interests.

\section{References}

1. P. Spolaore, C. Joannis-Cassan, E. Duran,A. Isambert, J. Biosci. Bioeng. 2006, 101, 87-96. DOI:10.1263/jbb.101.87

2. K. H. M. Cardozo, T. Guaratini, M. P. Barros, V. R. Falcao, A. P. Tonon, N. P. Lopes, S. Campos, M. A. Torres, A. O. Souza, P. Colepicolo,E. Pinto, Comp. Biochem. Physiol. C-Toxicol. Pharmacol. 2007, 146, 60-78.

DOI:10.1016/j.cbpc.2006.05.007

3. H. Qiao, C. Cong, C. Sun, B. Li, J. Wang,L. Zhang, Aquaculture, 2016, 452, 311-317.

DOI:10.1016/j.aquaculture.2015.11.011

4. Y.-H. Yang, L. Du, M. Hosokawa, K. Miyashita, Y. Kokubun, H. Arai,H. Taroda, J. Oleo Sci., 2017, ess16205.

5. Z.-K. Yang, Y.-F. Niu, Y.-H. Ma, J. Xue, M.-H. Zhang, W.-D. Yang, J.-S. Liu, S.-H. Lu, Y. Guan,H.-Y. Li, Biotechnol. Biofuels 2013, 6, 67. DOI:10.1186/1754-6834-6-67

6. Y. Chisti, Biotechnol. Adv. 2007, 25, 294-306. DOI:10.1016/j.biotechadv.2007.02.001

7. J. Lupette,C. Benning, Biochimie, 2020, 178, 15-25. DOI:10.1016/j.biochi.2020.04.022

8. M. Hamilton, S. Powers, J. Napier,O. Sayanova, Mar. Drugs, 2016, 14, 53. DOI: $10.3390 / \mathrm{md} 14030053$

9. K. Gharami, M. Das,S. Das, Neurochem. Int. 2015, 89, 51-62. DOI:10.1016/j.neuint.2015.08.014

10. P. C. Calder, Mol. Nutr. Food Res. 2012, 56, 1073-1080. DOI:10.1002/mnfr.201100710

11. K. C. Maki, A. L. Lawless, K. M. Kelley, M. R. Dicklin, A. L. Schild,T. M. Rains, Prostaglandins Leukot. Essent. Fatty Acids. 2011, 85, 143-148. DOI:10.1016/j.plefa.2011.06.005 
12. D. Mozaffarian,J. H. Wu, J. Am. Coll. Cardiol. 2011, 58, 20472067. DOI:10.1016/j.jacc.2011.06.063

13. D. Vasiljevic, M. Veselinovic, M. Jovanovic, N. Jeremic, A. Arsic, V. Vucic, A. Lucic-Tomic, S. Zivanovic, D. Djuric, V. Jakovljevic, Clin. Rheumatol. 2016, 35, 1909-1915. DOI:10.1007/ s10067-016-3168-2

14. C. E. Roynette, P. C. Calder, Y. M. Dupertuis,C. Pichard, Clin. Nutr. 2004, 23, 139-151. DOI:10.1016/j.clnu.2003.07.005

15. L. Luo, L. Ai, X. Liang, W. Xing, H. Yu, Y. Zheng, X. Wu, X. Liang,M. Xue, Aquac. Nutr. 2019, 25, 239-248.

DOI:10.1111/anu.12848

16. R. Zuo, Q. Ai, K. Mai, W. Xu, J. Wang, H. Xu, Z. Liufu,Y. Zhang, Aquaculture, 2012, 334-337, 101-109.

DOI:10.1016/j.aquaculture.2011.12.045

17. J. Ma, J. Wang, D. Zhang, T. Hao, J. Sun, Y. Sun,L. Zhang, Aquaculture, 2014, 433, 105-114.

DOI:10.1016/j.aquaculture.2014.05.042

18. B. M. Codabaccus, C. G. Carter, A. R. Bridle,P. D. Nichols, Aquaculture, 2012, 356, 135-140.

DOI:10.1016/j.aquaculture.2012.05.024

19. P. M. Kris-Etherton, W. S. Harris,L. J. Appel, Circulation, 2002, 106, 2747-2757. DOI:10.1161/01.CIR.0000038493.65177.94

20. O. P. Ward,A. Singh, Process Biochem., 2005, 40, 3627-3652. DOI:10.1016/j.procbio.2005.02.020

21. D. Ristić-Medić, V. Vučić, M. Takić, I. Karadžić,M. Glibetić, J. Serb. Chem. Soc. 2013, 78, 1269-1289.

DOI:10.2298/JSC130402040R

22. M. Guo, G. Chen, J. Chen,M. Zheng, J. Ocean Univ. 2019, 18, 1199-1206. DOI:10.1007/s11802-019-3946-y

23. T. Arao,M. Yamada, Phytochemistry, 1994, 35, 1177-1181. DOI:10.1016/S0031-9422(00)94817-9

24. G. Barceló-Coblijn,E. J. Murphy, Prog. Lipid Res. 2009, 48, 355-374. DOI:10.1016/j.plipres.2009.07.002

25. P. C. Calder, J. Nutr. 2012, 142, 592S-599S. DOI:10.3945/jn.111.155259

26. H. Chaves, R. B. Singh, S. Khan, A. Wilczynska,T. Takahashi, in The Role of Functional Food Security in Global Health, eds. R. B. Singh, R. R. Watson,T. Takahashi, Academic Press, 2019, p.^pp. Page.

27. A. P. Simopoulos, Asia Pac. J. Clin. Nutr. 2008, 17, 131-134.

28. P. C. Calder, Biochimie, 2009, 91, 791-795. DOI:10.1016/j.biochi.2009.01.008

29. J. Marchix, B. Choque, M. Kouba, A. Fautrel, D. Catheline,P. Legrand, The Journal of Nutritional Biochemistry, 2015, 26, 1434-1441. DOI:10.1016/j.jnutbio.2015.07.010

30. A. A. Welch, S. Shakya-Shrestha, M. A. Lentjes, N. J. Wareham,K.-T. Khaw, Am. J. Clin. Nutr. 2010, 92, 1040-1051. DOI:10.3945/ajen.2010.29457

31. Q. Hu, M. Sommerfeld, E. Jarvis, M. Ghirardi, M. Posewitz, M. Seibert,A. Darzins, Plant J. 2008, 54, 621-639.

DOI:10.1111/j.1365-313X.2008.03492.X

32. G. Antolín, F. V. Tinaut, Y. Briceño, V. Castaño, C. Pérez,A. I. Ramírez, Bioresour Technol, 2002, 83, 111-114. DOI:10.1016/ S0960-8524(01)00200-0

33. W. Parawira, Crit. Rev. Biotechnol. 2009, 29, 82-93. DOI:10.1080/07388550902823674
34. S.-J. Kim, S.-M. Jung, Y.-C. Park,K. Park, Biotechnol. Bioprocess Eng. 2007, 12, 441. DOI:10.1007/BF02931068

35. M. Oda, M. Kaieda, S. Hama, H. Yamaji, A. Kondo, E. Izumoto,H. Fukuda, Biochem. Eng. J. 2005, 23, 45-51. DOI:10.1016/j.bej.2004.10.009

36. Y. Zhang, M. A. Dubé, D. D. McLean,M. Kates, Bioresour Technol, 2003, 90, 229-240.

DOI:10.1016/S0960-8524(03)00150-0

37. A. C. Guedes,F. X. Malcata, Aquaculture, 2012, 10, 59-78.

38. C. Paliwal, M. Mitra, K. Bhayani, S. V. V. Bharadwaj, T. Ghosh, S. Dubey,S. Mishra, Bioresour. Technol. 2017, 244, 1216-1226. DOI:10.1016/j.biortech.2017.05.058

39. R. R. Guillard,J. H. Ryther, Can. J. Microbiol. 1962, 8, 229239. DOI: $10.1139 / \mathrm{m} 62-029$

40. M. Axelsson,F. Gentili, Plos One, 2014, 9, 6. DOI:10.1371/journal.pone.0089643

41. P. P. Lamers, C. C. van de Laak, P. S. Kaasenbrood, J. Lorier, M. Janssen, R. C. De Vos, R. J. Bino,R. H. Wijffels, Biotechnol. Bioeng. 2010, 106, 638-648. DOI:10.1002/bit.22725

42. M. Rahman, M. Aziz, R. A. Al-khulaidi, N. Sakib,M. Islam, J. Radiat. Res. Appl. Sci. 2017, 10, 140-147.

DOI:10.1016/j.jrras.2017.02.004

43. M. Sung, J.-I. Han, Bioresour. Technol. 2016, 205, 250-253. DOI:10.1016/j.biortech.2015.12.089

44. ISO-5508. Animal and Vegetable Fats and Oils-Analysis by Gas Chromatography of Methyl esters of Fatty Acids; ISO 5508: 1990; International Organization for Standardization: Geneve, Switzerland, 1990.

45. S. Gebreyowhans, J. Lu, S. Zhang, X. Pang,J. Lv, Int. Dairy J. 2019, 97, 158-166. DOI:10.1016/j.idairyj.2019.05.011

46. C. Cardoso, H. Pereira, J. Franca, J. Matos, I. Monteiro, P. Pousao-Ferreira, A. Gomes, L. Barreira, J. Varela, N. Neng, J. M. Nogueira, C. Afonso,N. M. Bandarra, Aquac. Int., 2020, 28, 711-727. DOI:10.1007/s10499-019-00489-w

47. E. K. Sitepu, K. Heimann, C. L. Raston,W. Zhang, Renew. Sust. Energ. Rev. 2020, 123, 109762.

DOI:10.1016/j.rser.2020.109762

48. M. D. Macías-Sánchez, A. Robles-Medina, E. Hita-Peña, M. J. Jiménez-Callejón, L. Estéban-Cerdán, P. A. González-Moreno, E. Molina-Grima, Fuel, 2015, 150, 14-20. DOI:10.1016/j.fuel.2015.01.106

49. M. O. Faruque, S. A. Razzak,M. M. Hossain, Catalysts, 2020, 10, 1025. DOI:10.3390/catal10091025

50. M. Passos, H. Alves, C. Momesso, F. Faria, G. Murata, M. Cury-Boaventura, E. Hatanaka, S. Massao-Hirabara,R. Gorjão, Lipids Health Dis. 2016, 15, 1-11. DOI:10.1186/s12944-016-0385-2

51. H. Cao, K. Gerhold, J. R. Mayers, M. M. Wiest, S. M. Watkins, G. S. Hotamisligil, Cell, 2008, 134, 933-944.

DOI:10.1016/j.cell.2008.07.048

52. A. Arsić, V. Vučić, J. Tepšić, S. Mazić, M. Djelić,M. Glibetić, Appl. Physiol. Nutr. Metab. 2012, 37, 40-47.

DOI:10.1139/h11-125

53. G. Huang, F. Chen, D. Wei, X. Zhang,G. Chen, Appl. energy, 2010, 87, 38-46. DOI:10.1016/j.apenergy.2009.06.016

54. A. Demirbas, Energy Conv. Manag. 2008, 49, 125-130. 
DOI:10.1016/j.enconman.2007.05.002

55. J. M. Marchetti, V. U. Miguel,A. F. Errazu, Renew. Sust. Energ. Rev. 2007, 11, 1300-1311. DOI:10.1016/j.rser.2005.08.006

56. E. Ehimen, Z. Sun,C. Carrington, Fuel, 2010, 89, 677-684. DOI:10.1016/j.fuel.2009.10.011

57. F. Ma,M. A. Hanna, Bioresour Technol, 1999, 70, 1-15.

58. A. Demİrbaș, Energy Conv. Manag. 2003, 44, 2093-2109. DOI:10.1016/S0196-8904(02)00234-0

59. I. Atadashi, M. Aroua, A. A. Aziz,N. Sulaiman, J. Membr. Sci. 2012, 421, 154-164. DOI:10.1016/j.memsci.2012.07.006

60. K. Pramanik, Renew. Energy. 2003, 28, 239-248. DOI:10.1016/S0960-1481(02)00027-7

61. U. Schuchardt, R. Sercheli,R. M. Vargas, J. Braz. Chem. Soc. 1998, 9, 199-210. DOI:10.1590/S0103-50531998000300002

62. D. A. G. Aranda, R. T. P. Santos, N. C. O. Tapanes, A. L. D. Ramos,O. A. C. Antunes, Catal. Lett. 2008, 122, 20-25. DOI:10.1007/s10562-007-9318-Z

63. I. M. Atadashi, M. K. Aroua, A. R. Abdul Aziz,N. M. N. Sulaiman, Renew. Sust. Energ. Rev. 2012, 16, 3456-3470. DOI:10.1016/j.rser.2012.03.004

64. H. I. El-Shimi, N. K. Attia, S. T. El-Sheltawy,G. I. El-Diwani, J. Sustain. Bio. Systems. 2013, 3, 224-233.

DOI:10.4236/jsbs.2013.33031
65. S. Velasquez-Orta, J. Lee,A. Harvey, Biochem. Eng. J. 2013, 76, 83-89. DOI:10.1016/j.bej.2013.04.003

66. T. Brody, Nutr. biochem. Elsevier, 1998.

67. R. A. Gibson, B. Muhlhausler,M. Makrides, Matern. Child Nutr. 2011, 7, 17-26. DOI:10.1111/j.1740-8709.2011.00299.X

68. M. Zhang, C. Y. Chen, C. H. You, B. J. Chen, S. Q. Wang,Y. Y. Li, Aquaculture, 2019, 505, 488-495.

DOI:10.1016/j.aquaculture.2019.01.061

69. E. Henrotte, R. S. N. M. Mandiki, A. T. Prudencio, M. Vandecan, C. Mélard,P. Kestemont, Aquac. Res. 2010, 41, e53-e61. DOI:10.1111/j.1365-2109.2009.02455.x

70. S. R. Wassall,W. Stillwell, Chem. Phys. Lipids. 2008, 153, 5763. DOI:10.1016/j.chemphyslip.2008.02.010

71. L. F. C. Castro, D. R. Tocher,O. Monroig, Prog. Lipid Res. 2016, 62, 25-40. DOI:10.1016/j.plipres.2016.01.001

72. P. Calder,R. Grimble, Eur. J. Clin. Nutr. 2002, 56, S14-S19. DOI:10.1038/sj.ejcn.1601478

73. K. C. Maki, K. Yurko-Mauro, M. R. Dicklin, A. L. Schild,J. G. Geohas, Prostaglandins Leukot. Essent. Fatty Acids, 2014, 91, 141-148. DOI:10.1016/j.plefa.2014.07.012

74. N. R. Council, Nutrient Requirements of Fish and Shrimp, The National Academies Press, Washington, DC, 2011.

\section{Povzetek}

Proučevali smo učinek neposrednih postopkov transesterifikacije na sestavo omega-3/6 ekstraktov iz Phaeodactylum tricornutum. Cilj tega dela je bil določiti metodo ekstrakcije, ki omogoča pridobitev najprimernejšega profila maščobnih kislin glede na njihove potencialne koristi za zdravje, še posebej za nadaljnjo uporabo v živilski industriji. Za določitev a-linolenske (ALA), linolne (LA), dokozaheksaenojske (DHA) in eikozapentaenojske kisline (EPA) je bilo uporabljenih sedem metod $\mathrm{z}$ uporabo kislin, baz in heterogenih katalizatorjev (metode od 1 do 7, skrajšano M1-M7). Za sestavo maščobnih kislin je bila $\mathrm{v}$ vseh primerih značilna največja prisotnost palmitinske (23.95-34.08 \%), palmitoleinske (30.94-35.56\%), oleinske kisline (3.00-7.41 \%) in EPA (0.5-6.45 \%). Izkoristek ekstrakcije nenasičenih maščobnih kislin je bil višji z dvostopenjskim postopkom transesterifikacije (M6, $63.65 \%$ ). Skupna vsebnost metilnih estrov maščobnih kislin (FAME), dobljena s kislinsko transesterifikacijo (M1), je dosegla približno $21 \%$ celokupne mase in $60 \%$ vseh lipidov. Višjo relativno vsebnost ALA (razmerje ALA/LA) smo dobili, če smo pred kislinsko katalizo izvedli stopnjo predhodne ekstrakcije lipidov (M4). Metoda transesterifikacije na osnovi alkalnega katalizatorja (katalizator $\mathrm{KOH}, \mathrm{M} 3$ ) je privedla do višjih relativnih vsebnosti DHA (razmerje DHA/EPA do 0.11), čeprav je bila pri tem vsebnost FAME 3.75-krat manjša od tiste, pridobljene s kislinsko transesterifikacijo (M1). Na splošno ta študija kaže, da neposredna transesterifikacija z alkalnim katalizatorjem (M3) izboljša določanje vsebnosti PUFA iz diatomej z učinkovitejšim postopkom ekstrakcije, ki temelji na transesterifikaciji, in tako omogoča natančnejšo oceno vrednosti biomase za uporabo $\mathrm{v}$ prehrambeni industriji.

Except when otherwise noted, articles in this journal are published under the terms and conditions of the Creative Commons Attribution 4.0 International License 